\title{
Learner Effectiveness: A Cause of Learner Strategy Use?
}

\author{
Mohammadreza Yousefi Halvaei, Ali Akbar Ansarin* \\ English Language Department, University of Tabriz, Iran \\ Corresponding author: Ali Akbar Ansarin, E-mail: Ansarin@tabrizu.ac.ir
}

\begin{tabular}{l} 
ARTICLE INFO \\
\hline Article history \\
Received: August 12, 2018 \\
Accepted: September 15, 2018 \\
Published: October 31, 2018 \\
Volume: 6 Issue: 4 \\
\hline
\end{tabular}

Conflicts of interest: None Funding: None

\begin{abstract}
The study of the individual learner differences including learner effectiveness has been a genuine concern for second language researchers. The present study strived to examine the impact of learner effectiveness on the language learners' learning strategy use. According to this purpose, first, the researchers developed the two-part 40-item learning strategy questionnaire of the study according to the strategy questionnaire developed by Wong and Nunan (2011). Second, they selected 441 students ( 224 male \& 217 female) studying at the first year of their graduate program at universities in East Azerbaijan Province (Iran) as the participants of the study. Third, they administered the questionnaire of the study to the chosen participants and asked them to complete it. Finally, the researchers employed the chi-square test to analyze the collected data of the study. Based on the results of the study, there were significant differences between the more effective and less effective EFL learners' use of language learning strategies. On the basis of these results, it was argued that the syllabus designers should include specific parts in the teaching materials of the EFL classrooms in which the learners become familiar with various learning strategies and are trained to employ the most efficient strategies for the performance of language learning tasks. Similarly, it was pointed out that the EFL teachers should familiarize their learners with the diverse language learning strategies and their predominant role in the process of second language acquisition.
\end{abstract}

Key words: Affective Factors, Cognitive Factors, Individual Learner Differences, Learner Effectiveness, Learning Strategies

\section{INTRODUCTION}

In foreign language learning, learners vary in terms of pace and the eventual level of language competence (Dörnyei, 2005). Ellis (2008) argued that the variation among language learners may arise from three categories of factors: social, cognitive, and affective. He contended that, among these categories, the cognitive and affective categories are learner-based in origin and are referred to as individual learner differences. These variables are persistent and consistent attributes which prompt the learner to approach the task of language learning in distinct ways (Skehan, 1989). The early studies of the learner differences took a predictive approach (Ellis, 2008) and categorized the language learners as "good and bad, intelligent and dull, motivated and unmotivated" (Horwitz, 2000 , p. 532) due largely to the fact that they endeavored to specify the learners who could succeed in language learning. Nonetheless, the recent studies of these variables have adopted and explanatory approach and have strived to underline the reasons behind the success of particular learners in language acquisition (Ellis, 2008). These studies have adopted more impartial terms such as "integratively and instrumentally motivated, anxious and comfortable, field independent and field sensitive, auditory and visual" (Horwitz, 2000, p. 532) to elucidate the students' learning behavior.

A close inspection of the related literature of the individual learner differences highlights the fact that learner strategies have captured the second language researchers' attention (Cohen, 1998; O’Malley \& Chamot, 1990; Oxford, 1990). A scrutiny of the empirical background of these strategies shows that the majority of their studies have been carried out in second language contexts (e.g., Naiman, Fröhlich, Stern, \& Todesco, 1978; Reiss, 1983 , 1985). Moreover, the empirical studies in the foreign language contexts (e.g., Bidabadi \& Yamat, 2010; Shakarami \& Abdullah, 2010) have made an endeavor to specify the relationship between these strategies and language learning. Nevertheless, there is not sufficient research on the effect of learner factors including learner effectiveness on the use of learning strategies. The present study endeavored to address this issue in the EFL context of Iran. More specifically, this study strived to answer the following question:

- How does learner effectiveness affect learners' use of learning strategies? 


\section{REVIEW OF THE RELATED LITERATURE}

\section{Learning Strategies}

Learning strategies are the specific mental and communicative procedures that learners employ in order to learn and use language (Chamot, 2005; O’Malley \& Chamot, 1990). They are the "behaviors or actions which learners use to make language learning more successful, self-directed and enjoyable" (Oxford, 1989, p. 237). They include "any thoughts, behaviors, beliefs, or emotions that facilitate the acquisition, understanding, or later transfer of new knowledge and skills" (Weinstein, Husman, \& Dierking, 2000, p. 727). It is argued that learning strategies are tools which "make learning easier, faster, more enjoyable, more self-directed, more effective, and more transferable to new situations" (Oxford, 1990, p. 8). In other words, these strategies define "the approach learners adopt in learning a second language and are influenced directly by learners' explicit beliefs about how best to learn" (Ellis, 2008, p. 703). In emphasizing their facilitative role in language learning, Oxford's (1999) pointed out that these strategies refer to "specific actions, behaviors, steps, or techniques that students use to improve their own progress in developing skills in a second or foreign language" (p. 518).

Oxford $(1990,1993,1996)$ contended that the diverse definitions of learning strategies emphasize that they are employed consciously to fulfill learning aims. Likewise, Cohen (1998) asserted that learning strategies are "learning processes which are consciously selected by the learner" (p. 4). This issue may distinguish learning strategies from other individual learner differences (Dörnyei, 2005). However, the investigation of learning strategies is indispensable. First, "learning styles and learning strategies are interrelated concepts, differing primarily in their breadth and stability" (p. 162). As Snow, Corno, and Jackson (1996) noted, a learning style is a "strategy used consistently across a class of tasks" (p. 281). Second, the empirical studies (e.g., Winne, 1995) have revealed that certain learning strategies are employed more consistently by the learners in comparison with others and are exploited by the learners as reservoirs to assist the self-regulated learners (Chamot \& Rubin, 1994). The self-regulated learners "seek to accomplish academic goals strategically and manage to overcome obstacles using a battery of resources" (Randi \& Corno, 2000, p. 651). Third, it is apparent that the good language learner "cannot be described in terms of a single set of strategies but rather through the ability to understand and develop a personal set of effective strategies" (Chamot \& Rubin, 1994, p. 372). Consequently, it is logical to specify the learning strategies as individual learner difference variables (Oxford, 2003).

\section{The Problems of Learning Strategy Research}

The literature of learning strategies is replete with diverse definitions of this construct (Green \& Oxford, 1995). However, there is not a watertight definition of these strategies (O’Malley, Chamot, Stewner-Manzanares, Russo, Kupper, 1985). More specifically, the various definitions of learning strategies do not distinguish them from the learners' everyday learning activities (Oxford, 2001). It is argued that the definitions lack the criteria which determine the differences between the learning in general and the strategies which are employed for learning (Oxford, 1996).

In an attempt to deal with this problem, Weinstein et al. (2000) argued that learning strategies have three main features including: goal-directedness, intentional invocation, and exertion of effort. Nonetheless, a close perusal of these criteria shows that: a) they are the main aspects of learner motivation; and b) they characterize the process of learning in general (Dörnyei, 2005). Moreover, it has been argued that the conscious use of these strategies by the learners may distinguish them from the everyday learning activities (Cohen, 1998). However, the issue of conscious use or choice is not sufficient to draw a distinction between the learning strategies and other learner activities due largely to the fact that some of the learners' academic choices such as the choice of the place for education may be non-strategies (Dörnyei, 2005). It seems that appropriateness is the only feature that underlines the distinction between learning strategies and other individual learner differences (Riding \& Rayner, 1998).

\section{Taxonomies of Learning Strategies}

The related literature of learning strategies underscores the fact that empirical studies of this construct have pursued different trends during the past four decades. The early studies (e.g., Naiman et al., 1978) tried to specify the learner characteristics which facilitated language learning. In general, the early studies underscored the fact that learners' active use of language learning tactics worked in tandem with their internal aptitude to promote language learning. The second phase of the empirical studies began in the 1980s (e.g., Reiss, 1983, 1985 ) and examined the effectiveness of learner strategies in the process of learning the target language (Wintergerst, DeCapua, Verna, 2003.). Nonetheless, none of these research lines has paid enough attention to the theoretical validity of the learning strategy construct (Dörnyei \& Skehan, 2003). Ellis (1994) pointed out that "definitions of learning strategies have tended to be ad hoc and atheoretical" (p. 533). These research lines have led to the development of certain learning strategy taxonomies including the ones provided by O’Malley and Chamot (1990) and Oxford (1990).

O'Malley and Chamot (1990) distinguished three types of learning strategies including cognitive, metacognitive, and socio-affective strategies. In this classification:

Cognitive strategies are the strategies involving the analysis, transformation, or the synthesis of learning materials. On the other hand, Metacognitive strategies are the strategies involving an attempt to regulate learning through planning, monitoring, and evaluating. Finally, socio-affective learning strategies are the strategies concerning the ways in which learners interact with the other users of the second language (Ellis, 2008, p. 705).

However, the categorization of strategies in this taxonomy is problematic (Hsiao \& Oxford, 2002). As Dörnyei (2005) noted, some of the strategies of the social/affective category (i.e., self-talk) refute the theoretical assumptions of the taxonomy. More specifically, since they cannot be 
integrated with the other categories, they treated as social/ affective learning instruments. It is argued that a further classification of these strategies to two categories (i.e., social \& affective) may promote the empirical validity of the taxonomy (Hsiao \& Oxford, 2002).

On the other hand, Oxford (1990) draws a distinction between direct and indirect strategies. As she noted, direct strategies include memorizing, analyzing, reasoning and guessing intelligently. These strategies "require the mental processing of the language" (p. 181). On the other hand, indirect strategies include things such as evaluating one's learning and cooperating with others. They "provide indirect support for language learning through focusing, planning, evaluating, seeking opportunities, controlling anxiety, increasing cooperation and empathy and other means" (p. 181).

Similar to the previous taxonomy, Oxford's (1990) taxonomy, which is named the Strategy Inventory for Language Learning, has certain problems. In this taxonomy, direct strategies comprise memory, cognitive, and compensation strategies while the indirect strategies involve metacognitive, affective, and social strategies. Dörnyei (2005) underlined the two controversial aspects of this taxonomy. First, the compensation strategies are closely connected to language use instead of language learning and since these processes are essentially separate from each other (Tarone, 1981), it is not logical to categorize the compensation strategies as language learning strategies. Second, although certain empirical studies have revealed that memory strategies are in fact a type of cognitive strategies, Oxford's (1990) taxonomy classifies them as independent categories. On the basis of these issues Wong and Nunan (2011) developed a strategy taxonomy which tackles the problems of these issues in a satisfactory way. The present study employed Wong and Nunan (2011) strategy taxonomy due to its solid theoretical foundation.

\section{METHOD}

\section{The Participants of the Study}

Based on the aims of the study 441 students (224 male \& 217 female) studying at the first year of their undergraduate program at universities in East Azerbaijan Province (Iran) were selected as the participants of the present study. All of these participants were chosen from among those who had taken the same University Entrance Examination administered by the Organization of Measurement and ranged in age from 18 to 22 . This examination involves various sections which are developed based on the students' high school courses. In this study, the participants' grades on the general English section of this test were employed for the selection of the participants. Based on the results of this examination the participants were divided into two groups: (i) more effective language learners with a grade of at least 66 on the 100-point entrance examination, and (ii) less effective learners with a grade of at most 33 on the 100-point entrance examination. On the basis of this classification, there were 232 more effective and 209 less effective participants in this study.

\section{The Instrument of the Study}

The researchers of the present study utilized a two-part 40item learning strategy questionnaire to collect the required data. In the first part of the questionnaire, the learners provided their personal information including their gender, age, native language, university major, and University Entrance Examination grade. The second part of this instrument was first devised by Willing (1994) and used in a modified version by Wong and Nunan (2011). It involved 30 items and asked the participants to indicate their attitude toward thirty key in-class and out-of-class strategies by rating them on a four-point scale (i.e., No, A Little, Good, \& Best). The participants' answers to the items of this part determined their language learning strategies. As Wong and Nunan (2011) contended, these strategies can be classified into four main types including: communicative, analytical, authority-oriented, and concrete. Based on the results of the statistical analysis, the Cronbach's Alpha coefficient of this questionnaire was .84 which is considered to be satisfactory (Pallant, 2007). Therefore, the questionnaire was regarded to be a suitable instrument for the purpose of the study.

\section{The Procedure of the Study}

On the basis of the purpose of the present study, first, the researchers developed the two-part 40-item learning strategy questionnaire of the study according to the strategy questionnaire developed by Wong and Nunan (2011). Second, they selected 441 students (224 male \& 217 female) studying at the first year of their graduate program at universities in East Azerbaijan Province (Iran) as the participants of the study. Third, they administered the questionnaire of the study to the chosen participants and asked them to complete it. Finally, the researchers employed the chi-square test to analyze the collected data of the study. More specifically, the researchers used the frequency of the participants' answers to each of the four-point scale (i.e., No, A Little, Good, \& Best) response choices of the items of the questionnaire to determine the differences between the more effective and less effective language learners' strategy use.

\section{RESULTS AND DISCUSSION}

The research question of the study examined the differences between more effective and less effective students' learning strategies. The results of the data analysis indicated that there were significant differences between these groups of learners in six items of the employed questionnaire of the study including: item 6 , item 9, item 12 , item 13, item 27 , and item 33. These results are provided below:

Item 6: In English class, I like to learn by reading.

Table 1 provides the frequency and percentage of the differences between these groups in regard to item 6 :

A chi-square test for independence was employed to determine the statistical significance of the difference between these groups. Table 2 shows the results of this test:

As shown in Table 2, there was a significant difference between the more effective and less effective EFL learners' 
responses to this item since the p-value .000 (marked as Sig.) was less than the level of significance .05 .

Item 9: In class, I like to learn by conversation.

Table 3 provides the frequency and percentage of the differences between these groups in regard to item 9:

A chi-square test for independence was employed to determine the statistical significance of the difference between these groups. Table 4 shows the results of this test:

As shown in Table 4, there was a significant difference between the more effective and less effective EFL learners' responses to this item since the p-value .000 (marked as Sig.) was less than the level of significance .05 .

Item 12: I like to have my own textbook.

Table 5 provides the frequency and percentage of the differences between these groups in regard to item 12:

A chi-square test for independence was employed to determine the statistical significance of the difference between these groups. Table 6 shows the results of this test:

As shown in Table 6, there was a significant difference between the more effective and less effective EFL learners' responses to this item since the p-value .000 (marked as Sig.) was less than the level of significance .05 .

Table 1. Frequency and percentage of more effective and less effective EFL learners' preference degree regarding item 6

\begin{tabular}{lcc}
\hline $\begin{array}{l}\text { Preference } \\
\text { degree }\end{array}$ & $\begin{array}{l}\text { More effective } \\
\text { learners } \boldsymbol{f}(\boldsymbol{\%})\end{array}$ & $\begin{array}{c}\text { Less effective } \\
\text { learners } \boldsymbol{f}(\boldsymbol{\%})\end{array}$ \\
\hline No & $114(49.1)$ & $32(15.3)$ \\
A Little & $63(27.2)$ & $56(26.8)$ \\
Good & $34(14.7)$ & $20(9.6)$ \\
Best & $21(9.1)$ & $101(48.3)$ \\
\hline
\end{tabular}

Table 2. Chi-square test of the more effective and less effective EFL learners' preference degree regarding item 6

\begin{tabular}{lccc}
\hline & Value & df & $\boldsymbol{p}$ \\
\hline Chi-Square & 101.632 & 3 & 0.000 \\
\hline
\end{tabular}

Table 3. Frequency and percentage of more effective and less effective EFL learners' preference degree regarding item 9

\begin{tabular}{lcc}
\hline $\begin{array}{l}\text { Preference } \\
\text { degree }\end{array}$ & $\begin{array}{l}\text { More effective } \\
\text { learners } \boldsymbol{f}(\boldsymbol{\%})\end{array}$ & $\begin{array}{c}\text { Less effective } \\
\text { learners } \boldsymbol{f}(\boldsymbol{\%})\end{array}$ \\
\hline No & $34(14.7)$ & $92(44.0)$ \\
A Little & $49(21.1)$ & $65(31.1)$ \\
Good & $50(21.6)$ & $31(14.8)$ \\
Best & $99(42.7)$ & $21(10.0)$ \\
\hline
\end{tabular}

Table 4. Chi-square test of the more effective and less effective EFL learners' preference degree regarding item 9

\begin{tabular}{lccc}
\hline & Value & df & $\boldsymbol{p}$ \\
\hline Chi-Square & 83.127 & 3 & 0.000 \\
\hline
\end{tabular}

Item 13. I like the teacher to explain everything to us.

Table 7 provides the frequency and percentage of the differences between these groups in regard to item 13:

A chi-square test for independence was employed to determine the statistical significance of the difference between these groups. Table 8 shows the results of this test:

As shown in Table 4.8, there was a significant difference between the more effective and less effective EFL learners' responses to this item since the p-value .000 (marked as Sig.) was less than the level of significance .05 .

Item 27: I like to learn English words by hearing them.

Table 9 provides the frequency and percentage of the differences between these groups in regard to item 27 :

A chi-square test for independence was employed to determine the statistical significance of the difference between these groups. Table 10 shows the results of this test:

As shown in Table 10, there was a significant difference between the more effective and less effective EFL learners' responses to this item since the p-value .000 (marked as Sig.) was less than the level of significance .05 .

Item 33: I like to learn by talking to friends in English.

Table 11 provides the frequency and percentage of the differences between these groups in regard to item 33:

Table 5. Frequency and percentage of more effective and less effective EFL learners' preference degree regarding item 12

\begin{tabular}{lcc}
\hline $\begin{array}{l}\text { Preference } \\
\text { degree }\end{array}$ & $\begin{array}{l}\text { More effective } \\
\text { learners } \boldsymbol{f}(\boldsymbol{\%})\end{array}$ & $\begin{array}{c}\text { Less effective } \\
\text { learners } \boldsymbol{f}(\boldsymbol{\%})\end{array}$ \\
\hline No & $117(50.4)$ & $29(13.9)$ \\
A Little & $71(30.6)$ & $32(15.3)$ \\
Good & $17(7.3)$ & $53(52.4)$ \\
Best & $27(11.6)$ & $95(45.5)$ \\
\hline
\end{tabular}

Table 6. Chi-square test of the more effective and less effective EFL learners' preference degree regarding item 12

\begin{tabular}{lccc}
\hline & Value & df & $\boldsymbol{p}$ \\
\hline Chi-Square & 123.360 & 3 & 0.000 \\
\hline
\end{tabular}

Table 7. Frequency and percentage of more effective and less effective EFL learners' preference degree regarding item 13

\begin{tabular}{lcc}
\hline $\begin{array}{l}\text { Preference } \\
\text { degree }\end{array}$ & $\begin{array}{l}\text { More effective } \\
\text { learners } \boldsymbol{f}(\boldsymbol{\%})\end{array}$ & $\begin{array}{c}\text { Less effective } \\
\text { learners } \boldsymbol{f}(\mathbf{\%})\end{array}$ \\
\hline No & $133(57.3)$ & $20(9.6)$ \\
A Little & $58(25.0)$ & $24(11.5)$ \\
Good & $25(10.8)$ & $82(39.2)$ \\
Best & $16(6.9)$ & $83(39.7)$ \\
\hline
\end{tabular}

Table 8. Chi-square test of the more effective and less effective EFL learners' preference degree regarding item 13

\begin{tabular}{lccc}
\hline & Value & df. & $\boldsymbol{p}$ \\
\hline Chi-Square & 172.533 & 3 & 0.000 \\
\hline
\end{tabular}


A chi-square test for independence was employed to determine the statistical significance of the difference between these groups. Table 12 shows the results of this test:

As shown in Table 12, there was a significant difference between the more effective and less effective EFL learners' responses to this item since the p-value .000 (marked as Sig.) was less than the level of significance .05 .

\section{DISCUSSION}

The research question of the present study aimed to determine the significant differences between more effective and less effective EFL learners' learning strategies. The results showed that there were significant differences between the learning strategies of these groups. A close inspection of the results showed that the more effective learners' preferred communicative (Wong \& Nunan, 2011) learning strategies and the less effective learners preferred auditory-oriented (Wong \& Nunan, 2011) learning strategies. These results are in line with the results of the studies by Willing (1994), Nunan (1991) Gan (2004) and Wong and Nunan (2011). As Willing (1994) argued, these results may be attributed to the more effective learners' field independence and autonomy in lan-

Table 9. Frequency and percentage of more effective and less effective EFL learners' preference degree regarding item 27

\begin{tabular}{lcc}
\hline $\begin{array}{l}\text { Preference } \\
\text { degree }\end{array}$ & $\begin{array}{l}\text { More effective } \\
\text { learners } \boldsymbol{f}(\boldsymbol{\%})\end{array}$ & $\begin{array}{c}\text { Less effective } \\
\text { learners } \boldsymbol{f}(\boldsymbol{\%})\end{array}$ \\
\hline No & $32(13.8)$ & $85(40.7)$ \\
A Little & $34(14.7)$ & $71(34.0)$ \\
Good & $60(25.9)$ & $34(16.3)$ \\
Best & $106(45.7)$ & $19(9.1)$ \\
\hline
\end{tabular}

Table 10. Chi-square test of the more effective and less effective EFL learners' preference degree regarding item 27

\begin{tabular}{lccc}
\hline & Value & df & $\boldsymbol{p}$ \\
\hline Chi-Square & 103.873 & 3 & 0.000 \\
\hline
\end{tabular}

Table 11. Frequency and percentage of more effective and less effective EFL learners' preference degree regarding item 33

\begin{tabular}{lcc}
\hline $\begin{array}{l}\text { Preference } \\
\text { degree }\end{array}$ & $\begin{array}{c}\text { More effective } \\
\text { Learners } \boldsymbol{f}(\mathbf{\%})\end{array}$ & $\begin{array}{c}\text { Less effective } \\
\text { learners } \boldsymbol{f}(\boldsymbol{\%})\end{array}$ \\
\hline No & $41(17.7)$ & $94(45.0)$ \\
A Little & $26(11.2)$ & $78(37.3)$ \\
Good & $81(34.9)$ & $18(8.6)$ \\
Best & $84(36.2)$ & $19(9.1)$ \\
\hline
\end{tabular}

Table 12. Chi-square test of the more effective and less effective EFL learners' preference degree regarding item 33

\begin{tabular}{llll}
\hline & Value & df & $\boldsymbol{p}$ \\
\hline Chi-Square & 127.064 & 3 & 0.000 \\
\hline
\end{tabular}

guage learning. He further stated that "there can be a certain self-directedness involved in deliberately using interactions for learning purposes, and in this way an underlying field-independence may show itself" (p. 153). Moreover, they may be ascribed to the less effective learners' field dependence (Willing, 1994). In other words, the less effective learners require a structure for learning and seek to progress in the process of language acquisition in a sequential way. Based on this cognitive style preference, they are generally passive and depend on the teacher in the classroom context (Wong \& Nunan, 2011).

Furthermore, as Wong and Nunan (2011) contended, these results may be attributed to the more effective language learners' authentic use of the language in both the context of the classroom and the appropriate contexts out of the classroom. They explained that the more effective learners focus on the use of the second language by means of authentic conversations with their peers and learn the target language vocabulary items and structures by hearing them. Consequently, these learners are more communicatively competent than the other learners. On the other hand, the less effective learners' strategy use may be attributed to their focus on the usage of the second language. As Wong and Nunan (2011) pointed out, these learners focus on the reading materials and rely on the teacher in the classroom. As a result, they are less communicatively competent in comparison with the more effective language learners.

\section{CONCLUSION}

The present study strived to determine the effect of learner effectiveness on the language learners' use of language learning strategies. That is, it tried to examine the use of learning strategies by the more effective and less effective learners. The results of the study showed that there were significant differences between more effective and less effective EFL learners' use of language learning strategies. Based on these results, it is recommended that the syllabus designers include specific parts in the teaching materials of the EFL classrooms in which the learners become familiar with various learning strategies and receive training in the use of the most efficient strategies for the performance of language learning tasks. Similarly, it is suggested that EFL teachers familiarize their learners with diverse language learning strategies and their predominant role in the process of second language acquisition. These teachers should train their learners to employ different learning strategies and take on the responsibility for their own learning.

Nevertheless, it is clear that further studies are needed to deal with the investigated issue of the present study in various learning contexts. It is suggested that the second language researchers replicate this study in various educational settings. Furthermore, it is recommended that the future studies consider the possible effects of learner attributes including mother tongue and age group on the relationship between learner effectiveness and learning strategy use. Moreover, it is suggested that the future studies deal with the other individual learner differences (e.g., learning styles) in foreign language contexts. Finally, it is recommended that the future studies examine diverse learner differences in second language learning contexts. 


\section{REFERENCES}

Bidabadi, F. S., \& Yamat, H. (2010). The relationship between listening strategies employed by Iranian EFL freshman university students and their learning style preferences. European Journal of Social Sciences, 16(3), 351-359.

Chamot, A. U. (2005). Language learning strategy instruction: Current issues and research. Annual Review of Applied Linguistics, 25, 112-130.

Chamot, A. U., \& Rubin, J. (1994). Comments on Janie Rees-Miller's “A critical appraisal of learner training: Theoretical bases and teaching implications". TESOL Quarterly, 28, 771-776.

Cohen, A. D. (1998). Strategies in learning and using a second language. Harlow: Longman.

Dörnyei, Z. (2005). The psychology of the language learner: Individual differences in second language acquisition. Mahwah: Lawrence Erlbaum.

Dörnyei, Z., \& Skehan, P. (2003). Individual differences in second language learning. In C. J. Doughty \& M. H. Long (Eds.), The handbook of second language acquisition (pp. 589-630). Oxford: Blackwell.

Ellis, R. (2008). The study of second language acquisition $\left(2^{\text {nd }}\right.$ Ed.). Oxford: Oxford University Press.

Gan, Z. (2004). Attitudes and strategies as predictors of self-directed language learning in an EFL context. International Journal of Applied Linguistics, 14(3), 389-411.

Green, J. M., \& Oxford, R. L. (1995). A closer look at learning strategies, L2 proficiency, and gender. TESOL Quarterly, 29(2), 261-297.

Horwitz, E. K. (2000). Teachers and students, students and teachers: An ever-evolving partnership. The Modern Language Journal, 84, 523-535.

Hsiao, T. Y., \& Oxford, R. L. (2002). Comparing theories of language learning strategies: A confirmatory factor analysis. Modern Language Journal, 86(3), 368-383.

Naiman, N., Fröhlich, M., Stern, H., \& Todesco, A. (1978). The good language learner. Toronto: Ontario Institute for Studies in Education.

Nunan, D. (1991). Language teaching methodology. London: Prentice Hall.

O’Malley, J. M., \& Chamot, A. U. (1990). Learning strategies in second language acquisition. New York: Cambridge University Press.

O’Malley, J. M., Chamot, A. U., Stewner-Manzanares, G., Russo, G., \& Kupper, L. (1985). Learning strategy applications with students of English as a second language. TESOL Quarterly, 19 (4), 285-296.

Oxford, R. L. (2003). Language learning styles and strategies: Concepts and relationships. IRAL, 41 (4), 271-278.

Oxford, R. L. (2001). Language learning styles and strategies. In M. Celce-Murcia (Ed.), Teaching English as a second or foreign language (pp. 359-366). Boston: Heinle \& Heinle.

Oxford, R. L. (1999). Learning strategies. In B. Spolsky (Ed.), Concise encyclopedia of educational linguistics (pp. 518-522). Oxford: Elsevier.
Oxford, R. L. (1996). Afterword: What have we learned about language learning strategies around the world? In R. L. Oxford (Ed.), Language learning strategies around the world: Cross-cultural perspectives (pp. 247-249). Honolulu: University of Hawaii Press.

Oxford, R. L. (1993). Research on second language learning strategies. Annual Review of Applied Linguistics, 13, $175-187$.

Oxford, R. L. (1990). Language learning strategies: What every teacher should know. New York: Newbury House.

Oxford, R. L. (1989). Use of language learning strategies: A synthesis of studies with implications for strategy training. System, 17, 235-247.

Pallant, J. (2007). SPSS survival manual: A step by step guide to data analysis using SPSS for windows ( $3^{\text {rd }} \mathrm{Ed}$.). Berkshire: McGraw-Hill House.

Randi, J., \& Corno, L. (2000). Teacher innovations in self-regulated learning. In M. Boekaerts, P. R. Pintrich \& M. Zeidner (Eds.), Handbook of self-regulation (pp. 651-685). San Diego: Academic Press.

Reiss, M. A. (1983). Helping the unsuccessful language learner. The Canadian Modern Language Review, 39, 257-266.

Reiss, M. A. (1985). The good language learner: Another look. The Canadian Modern Language Review, 41, 511-523.

Riding, R., \& Rayner, S. G. (1998). Cognitive styles and learning strategies: Understanding style differences in learning and behavior. London: David Fulton.

Shakarami, A., \& Abdullah, M. (2010). Iranian engineering and political science graduate students studying abroad. Educational Research and Reviews, 5(2), 35-45.

Skehan, P. (1989). Individual differences in second language learning. London: Edward Arnold.

Snow, R. E., Corno, L., \& Jackson, D. N. (1996). Individual differences in affective and conative functions. In D. C. Berliner \& R. C. Calfee (Eds.), Handbook of educational psychology (pp. 243-310). New York: Macmillan.

Tarone, E. (1981). Some thoughts on the notion of communication strategy. TESOL Quarterly, 15, 285-295.

Weinstein, C. E., Husman, J., \& Dierking, D. R. (2000). Self-regulation interventions with a focus on learning strategies. In M. Boekaerts, P. R. Pintrich \& M. Zeidner (Eds.), Handbook of self-regulation (pp. 727-747). San Diego: Academic Press.

Willing, K. (1994). Learning strategies in adult migrant education. Sydney: National Centre for English Language Teaching and Research.

Winne, P. H. (1995). Inherent details in self-regulated learning. Educational Psychologist, 30, 173-187.

Wintergerst, A. C., DeCapua, A., \& Verna, M. A. (2003). Conceptualizing learning style modalities for ESL/EFL students. System, 31 (1), 85-106.

Wong, L. L. C., \& Nunan, D. (2011). The learning styles and strategies of effective language learners. System, 39, 144-163. 